todas las prácticas que le parecen supersticiosas, incluso las de la religión, mientras que Ciruelo se limita a pedir que se guarden los preceptos eclesiásticos para que tales prácticas queden libres de sospecha.

Gracias a su interés por investigar y explicar las supersticiones, para luego reprobarlas, Ciruelo dejó una obra que fue valiosa para su época y que sigue siéndolo. Su disciplina científica, mantenida con cierto rigor, nos permite llegar al conocimiento de un aspecto importante de la vida del siglo XvI.

Adelphi College (Carden City, N. Y.)

A. V. Ebersole, JR.

\title{
¿SANTILLANA O SUERO DE RIBERA?
}

El Villancico a unas tres hijas suyas se ha asociado durante tanto tiempo al nombre del Marqués de Santillana, que cuesta trabajo desligarlo de él y admitir que esa paternidad es improbable, o en todo caso insegura. Rafael Lapesa (La obra literaria del Marqués de Santillana, Madrid, 1957, pp. 65-73, 320-326) se ha enfrentado con escrupulosa objetividad a los pros y a los contras. La atribución a Santillana es tardía: figura en los dos textos impresos del siglo xvi; en cambio, los dos manuscritos, del siglo xv, lo atribuyen a Suero de Ribera. Sin embargo, dice Lapesa, "por ahora la balanza se inclina a favor de Santillana" (p. 67): "es mejor poeta, autor indiscutido de la serranilla cortés a sus hijas similar al Villancico, y seguro conocedor de las pastorelas gallego-portuguesas" (p. 325); además, "su Querella de amor ofrece la misma alternancia de octavas narrativas y canciones líricas" (p. 67). Finalmente, "el engaste de estribillos tradicionales en un poema aristocrático responde a la amorosa dignificación de lo popular de que son muestra las serranillas y más tarde los Refranes que dicen las viejas tras el fuego" (p. 68).

Este último argumento es quizá el menos sólido. El Villancico responde, en efecto, a la corriente de dignificación de la poesía popular que estaba tomando cuerpo a mediados del siglo xv. Pero éfue Santillana un exponente de ella? ¿Santillana, que despreciaba los romances y cantares del vulgo inculto? La serranilla es un género aristocrático, sin más que una vaga relación temática con los villancicos populares. Y los Refranes... ¿son del Marqués? La moda popularizante es totalmente ajena al espíritu de la Castilla de Juan II. Sus comienzos están fuera de la Península, en la corte napolitana de Alfonso V. Aquí es donde se cantan por primera vez romances viejos españoles y se escriben, también por vez primera, romances al estilo de los antiguos. Ahora bien, el otro autor posible del Villancico pasó la mayor parte de su vida en Nápoles, y fue poeta de la corte de Alfonso. Me parece que en el platillo de Suero de Ribera hay que poner, junto a las dos atribuciones del siglo xv, esa presencia suya en el ambiente mismo en que se inició la valoración de la poesía popular hispánica. 